\title{
A new pleurocystitid blastozoan from the Middle Devonian of the Eifel (Germany) and its phylogenetic importance
}

\author{
Elise Nardin and Jan Bohatý \\ Acta Palaeontologica Polonica 58 (3), 2012: 533-544 doi: http://dx.doi.org/10.4202/app.2011.0116
}

Rich echinoderm fauna from the Middle Devonian of the Eifel (Rhenish Massif, Germany)

has yielded specimens of the rare recumbent pleurocystitid rhombiferans. Regulaecystis testudineus sp. nov. extends the stratigraphic range of the pleurocystitids to the Eifelian (Middle Devonian). Specimens show a strongly inflated and ornamented theca, which isunusual for the European pleurocystitids. Phylogenetic analysis of all described pleurocystitid genera suggests a close relationship of Regulaecystis with the other Devonian genera. Results indicate that the degree of inflation and of ornamentation of the theca can be interpreted as convergences within the pleurocystitids due to environmental conditions (such as surface consistency, hydrodynamism). $R$. testudineus sp. nov. was living as a strict epibenthic vagile organism; lying on muddy soft to firm substrates in quiet to agitated shallow warm water environments.

Key words: Echinodermata, Blastozoa, Pleurocystitidae, Regulaecystis, evolution, palaeoecology, Eifelian, Devonian, Rhenish Massif, Germany.

Elise Nardin [elnardin@gmail.com], CNRS, UMR 5563 GET, OMP, 14 avenue Edouard Belin, F-31400 Toulouse, France; Jan Bohatý [bohaty.jan@ gmail.com], Institut für Geologie und Mineralogie der Universität zu Köln, Zülpicher Str. 49A, D-50674 Köln (Cologne), Germany.

This is an open-access article distributed under the terms of the Creative Commons Attribution License (for details please see creativecommons.org), which permits unrestricted use, distribution, and reproduction in any medium, provided the original author and source are credited. 
